\title{
Öğretmenlerin Uzaktan Eğitime Yönelik Tutumları ve Covid-19 Korkularının Farklı Değişkenler Açısından İncelenmesi
}

\section{Examining Teachers' Attitude Towards Distance Education and Covid-19 Fears in Terms of Different}

Variables

\section{Gülçin KARAKUŞ ${ }^{1}$, Zeynep Bahar ERŞEN²}

\begin{abstract}
Öz
Bu çalışmanın amacı, öğretmenlerin uzaktan eğitime yönelik tutumları ile Covid-19 korkularını farklı değişkenler açısından incelemektir. Bunun yanında, çalışmanın bir diğer amacı ise öğretmenlerin uzaktan eğitime yönelik tutumları ile Covid-19 korkuları arasındaki ilişkiyi belirlemektir. Araştırmanın örneklemini farklı branşlarda çalışan 150 öğretmen oluşturmaktadır. Çalışmada tarama modeli kullanılmıştır. Çalışmada veri toplama aracı olarak Ağır (2007) tarafından geliştirilen Uzaktan Eğitime Yönelik Tutum Ölçeği ve Arpacı, Karataş ve Baloğlu (2020) tarafından geliştirilen Covid-19 Fobisi Ölçeği kullanılmıştır. Araştırmadan elde edilen sonuçlar; öğretmenlerin uzaktan eğitime yönelik tutumların olumsuz olduğunu ve Covid-19 korku düzeylerinin düşük olduğunu göstermektedir. Bununla birlikte çalışmada öğretmenlerin uzaktan eğitime yönelik tutumları ile Covid-19 korku düzeyleri arasında anlamlı bir ilişki olmadığı belirlenmiştir.
\end{abstract}

Anahtar Kelimeler

Uzaktan eğitim

Tutum

Covid-19 Korkusu

Öğretmenler

Abstract

The aim of this study is to examine teachers' attitudes towards distance education and Covid-19 fears in terms of different variables. In addition, another aim of the study is to determine the relationship between teachers' attitudes towards distance education and Covid-19 fears. The sample of the study consists of 150 teachers working in different branches. Survey model was used in the study. In the study, the Attitude Scale towards Distance Education developed by Ağır (2007) and the Covid-19 Phobia Scale developed by Arpacı, Karataş, and Baloğlu (2020) were used as data collection tools. Results obtained from the research shows that teachers' attitudes towards distance education are negative and Covid-19 fear levels are low. However, in the study, it was determined that there was no significant relationship between teachers' attitudes towards distance education and Covid-19 fear levels.

Keywords

Distance education

Attitude

Fear of covid-19

Teachers

$\begin{array}{lll}\text { Başvuru Tarihi/Received } & \text { Kabul Tarihi /Accepted } \\ 18.06 .2021 & 29.11 .2021 & \text { I Araştırma Makalesi / Research Article I }\end{array}$

18.06.2021 29.11.2021

\section{Suggested APA Citation/Önerilen APA Atıf Biçimi:}

Karakuş, G., \& Erşen, Z. B. (2021). Examining teachers' attitude towards distance education and Covid-19 fears in terms of different variables. Manisa Celal Bayar University Journal of the Faculty of Education, 9(2), 66-85. https://doi.org/10.52826/mcbuefd.954341.

\footnotetext{
${ }_{1}^{1}$ Sorumlu Yazar, Dr., Sivas Milli Eğitim Müdürlüğü, Sivas, TÜRKIYE; (iD https://orcid.org/0000-0002-0587-4079

2 Dr. Öğr. Üyesi, Selçuk Üniversitesi Eğitim Fakültesi, Matematik Eğitimi, Konya, TÜRKIYE; (iD https://orcid.org/0000-0002-7928-2535
} 


\section{GİRIŞ}

Toplum sağlığını etkileyen geniş kapsamlı sorunlar bireylerde uzun süreli etkisi devam eden sağlık sorunlarına yol açabilmektedir. 2019 yılı aralık ayında ilk olarak Çin'de görülen ve zamanla dünyanın diğer bölgelerine yayılan Covid-19 salgını da insan hayatını pek çok açıdan olumsuz yönde etkilemektedir. Salgın beraberinde sadece enfeksiyondan kaynaklı ölüm riskini değil; aynı zamanda bireyler için psikolojik bir baskıyı da gündeme getirmiştir. Yaşanan sürecin oluşturduğu psikolojik sorunlar bireylerde kaygı, korku ve endişe gibi sağlık sorunlarına yol açmaktadır (Cao, Fang, Hou, Han, Xu, Dong \& Zheng, 2020). Bireylerde oluşan bu kaygı temelde salgından uzak durmak amacıyla uygulanan karantinaya bağlı olarak insanlar arasında giderek artan sosyal mesafenin bir sonucudur. Ancak yaşanması muhtemel uzun süreli kaygı ise kaygı bozukluğuna da neden olabilmektedir (Xiao, 2020).

Görüldüğü gibi, günlük hayatta karşılaşılan tehditler bireyin yaşamını doğrudan etkilemektedir. Bireysel özelliklere bağlı olarak değişim gösteren kaygı bireyin geleceğe dair hedeflerini, planlarını ve isteklerini etkilendiği takdirde daha belirgin olarak görülür. Düşük ya da yüksek düzeydeki kaygı eğitim ortamında mesleki alan başarısını ve yaşam kalitesini etkileyebilmektedir (Bayraktar, Tozoğlu, ve Acar, 2014). Toplumda öğretmenlik mesleğine yönelik olarak öngörülen beklentinin yüksek olması öğretmenlerin de diğer mesleklere göre daha fazla kaygı hissetmelerine neden olabilir (Öztürk, Şahin, Demir ve Arcagök, 2019). Mesleki açıdan başarısız olma ihtimali, toplumsal etkileşimdeki sınırlandırılma, yaşanan bu süreçte eğitime normal seyrinde devam edememe, başlangıçta belirlenen hedeflere ulaşamama, yeni normalleşmeye, öğretimin farklılaşan yapısına adapte olmama gibi endişeler öğretmenlerin kaygılarının artmasına neden olabilir. Mesleki açıdan olumsuz olarak değerlendirilme, bu doğrultuda yetersizlik ve suçluluk hissetme, öğretmenin iş, akademik, sosyal ve özel yaşamını olumsuz etkilediği takdirde birey var olan potansiyelini tam olarak kullanamayabilir. Modern toplumlarda mesleki alanda yaşanan bu tür sorunların belirlenmesi ve gereken tedbirlerin alınması toplumsal yapının devamlılığı için önemli görülmektedir (Yıldırım, Çırak ve Konan, 2011).

Özelde insan psikolojisi üzerindeki bu etkilerinin yanı sıra salgının tüm dünya genelinde pek çok alanda etkili olduğu görülmektedir. Eğitim kurumlarının kapatılması ve derslerin ve sınavların ertelenmesi veya uzaktan / uzaktan öğrenme yöntemlerinin kullanılması sürecin eğitime olumsuz etkileri olarak sıralanabilir (Cao, Fang, Hou, Han, Xu, Dong \& Zheng, 2020).

Salgın nedeniyle değişen şartlara bağlı olarak dünya çapında, her geçen gün pek çok öğretmen ve öğrenci uzaktan eğitime yönelmektedir. Eğitim kurumları uzaktan eğitime yönelik programlar ve alt yapı özelliklerini gözden geçirmektedir ancak pek çok kurum için bu durum teknik boyutu ile sorun oluşturmaktadır. Sadece teknik unsurlarla sınırlı olmayan başka problemler de süreçte görülmeye başlanmıştır. Öğretmen ve öğrencilerin uzaktan eğitimle ilgili bilgilendirilmeleri, yoğunluk nedeniyle ağ bağlantılarında yaşanan sorunlar, ev ortamında bilgisayar imkânı ve internet bağlantısı olmadığı için sürece katılamayan öğrencilerin yaşadıkları problemler, uygulamalı (laboratuvar, müzik, sanat gibi) derslerin uzaktan eğitim ile yapılmasında yaşanan güçlükler bu süreçte karşılaşılan diğer sorunlar arasında sayılabilir. Ayrıca uzaktan eğitimin kalitesi de bu noktada incelenmesi gereken hususlardandır (Sahu, 2020). Her ne kadar zaman ve mekân sınırlamasının olmaması nedeniyle yararlı olarak değerlendirilse de uzaktan eğitim faaliyetlerinde öğretmenlerin dikkat etmeleri gereken birtakım unsurlar yer almaktadır. Örneğin uzaktan eğitim sürecinde değerlendirme aşamasında öğretmenlerin dikkatli bir planlanma yapmaları ve süreci bu doğrultuda yürütmeleri gerekir. Bununla birlikte ek materyallerin temin edilmesi, denetlenmesi ve kullanımı, uzaktan eğitimde öğrencinin katılımının, ders takibinin kontrol edilmesi öğretmenler için zaman zaman sorun teşkil etmektedir (Gonzalez vd., 2020). Bu durum öğretmenlerin uzaktan eğitime yönelik olumsuz bir tutuma sahip olmalarına neden olabilir. Öğretmenin uzaktan eğitime karşı olumsuz bir tutuma sahip olması durumunda uzaktan eğitimin kendisine sunduğu olanaklardan faydalanması zor olacaktır ve öğrenme süreci olumsuz olarak etkilenecektir (Birişçi, 2013).

|Manisa Celal Bayar University Journal of The Faculty of Education, 2021, Vol.9, No. 2 | 
Covid-19 salgını sürecinde öğrenci ve öğretmenlerin eve kapanmalarının eğitimde olumlu yansımaları da görülmektedir. Örneğin salgın nedeniyle yürütülen uzaktan eğitim faaliyetleri bireysel öğrenme çabalarının artmasını, daha fazla ve çeşitli öğrenme stratejilerinin kullanılmasını sağlamıştır ve bu stratejilerin etkinliğinin arttı̆̆ı görülmüştür (Gonzalez vd., 2020).

Alan yazında yapılan çalışmalar incelendiğinde Covid-19 salgını sürecinde ilkokul öğrencilerinin uzaktan eğitim sürecine yönelik çalışmalara (Ilmiyah \& Setiawan, 2020; Setiawan, 2020), okul kapanma sürecinin etkilerine yönelik çalışmalara (Viner vd., 2020; Van \& Parolin, 2020), Covid-19 sürecinde uzaktan eğitime geçişte yaşanan sorunlara yönelik çalışmalara (Basilaia \& Kvavadze, 2020; Sahu, 2020), Covid-19 salgınında öğrencilerin yaşadığı psikolojik sorunlara (Liu, Liu, \& Zhong, 2020; Pragholapati, 2020 ) ve sağlik sorunlarına yönelik (Rundle, Park, Herbstman, Kinsey \& Wang, 2020) çalışmalara, Covid-19 salgınının eğitime etkisine yönelik çalışmalara (Burgess \& Sievertsen, 2020; Sahu, 2020), süreçte risk yönetimine yönelik çalışmalara (Wang, Cheng, Yue \& McAleer, 2020), Covid-19 salgınının öğrencilerin performansına etkisini inceleyen çalışmalara (Gonzalez vd., 2020) rastlanılmıştır.

Uzaktan eğitimle ilgili yapılan çalışmalar incelendiğinde alan yazında öğrencilerin uzaktan eğitime yönelik tutumlarını belirlemeye yönelik çalışmalara (Biriş̧̧i, 2013; Ural, 2007; Aydın, 2012; Ojo ve Olakuluhin, 2006; Ateş ve Altun, 2008), uzaktan eğitimin üstün zekâlı çocukların eğitimindeki yerine yönelik çalışmalara (Cırık, 2016; Thomson, 2010; Sanderson ve Greenberger, 2010), uzaktan eğitim ve örgün eğitimi karşılaştıran çalışmalara (Cavanaugh, 2001; Suanpang, Petocz ve Walter, 2004; Balaman, 2018; Tezcan, 2001), uzaktan eğitimde kullanılan materyallere yönelik çalışmalara (Bodur, 2002; Birol ve Teker, 2002), uzaktan eğitime yönelik öğretmen görüşlerinin incelendiği çalışmalara (Hamutoğlu, Gültekin ve Savaşçı,2019; Çelen, Çelik ve Seferoğlu, 2013) akademisyen görüşlerinin incelendiği çalışmalara (Tuncer ve Tanaş, 2011; Yılmaz ve Aktuğ, 2011), uzaktan eğitimde yaşanabilecek teknik sorunlara odaklanan (Bates, 2005) çalışmalara rastlanmaktadır. Buna karşın farklı sınıf seviyelerinde görev yapan öğretmenlerin uzaktan eğitim sürecine ilişkin tutumlarını belirlemeye yönelik çalışmalar sinırlı sayıdadır (Ağır, 2007; Kocayiğit ve Uşun, 2020; Moçoşoğlu ve Kaya, 2020). Salgın hastalıklar eğitim öğretim süreci üzerinde etkili olmaktadır. Salgın sürecinde öğretmelerin eğitim öğretime yönelik kaygı ve tutumlarının belirlenmesi bu süreç içerisindeki eğitim öğretim faaliyetlerinin nitelikleri hakkında da ipuçları sunmaktadır. Buna karşın alan yazında öğretmenlerin salgı sürecindeki fobileri ile eğitime yönelik tutumları arasındaki ilişkileri ortaya koyan bir çalışmaya rastlanmamıştır. Bu bağlamda çalışmada, öğretmenlerin uzaktan eğitime yönelik tutumları ve Covid-19 korkularının farklı değişkenler açısından incelenmesi; tutum ve korku düzeyleri arasında nasıl bir ilişki olduğunun belirlenmesi amaçlanmaktadır. Bu çalışmanın araştırma problemleri şu şekilde belirlenmiştir;

1. Öğretmenlerin uzaktan eğitime yönelik tutumları nasıldır?

2. Branş değişkenine göre öğretmenlerin uzaktan eğitime yönelik tutumlarında anlamlı bir farklılık var midir?

3. 3.Cinsiyet değişkenine göre öğretmenlerin uzaktan eğitime yönelik tutumlarında anlamlı bir farklılık var midır?

4. Kıdem değişkenine göre öğretmenlerin uzaktan eğitime yönelik tutumlarında anlamlı bir farklılık var midır?

5. Öğretmenlerin koronavirüs korku düzeyleri nasıldır?

6. Branş değişkenine göre öğretmenlerin koronavirüs korku düzeylerinde anlamlı bir farklılık var mıdır?

7. Cinsiyet değişkenine göre öğretmenlerin koronavirüs korku düzeylerinde anlamlı bir farklılık var mıdır?

8. Kıdem değişkenine göre öğretmenlerin koronavirüs korku düzeylerinde anlamlı bir farklılık var mıdır?

9. Öğretmenlerin uzaktan eğitime yönelik tutumları ile koronavirüs fobi düzeyleri arasında anlamlı bir ilişki var midır? 


\section{YÖNTEM}

Bu çalışmada tarama (survey) modeli kullanılmıştır. Tarama modeli, örneklem olarak belirlenen katılımcıların önceden belirlenen sorulara verdikleri cevapların bir araya getirilmesi ile veri toplanılmasını sağlayan bir yöntemdir (Check \& Schutt, 2012). Tarama modeli sosyal bilimler alanında yapılan çalışmalarda sıklıkla tercih edilmektedir (Singleton \& Straits, 2009).

\section{Çalışma Grubu}

Çalışma farklı branşlarda görev yapan 150 öğretmen ile gerçekleştirilmiştir. Yaşanılan salgın süreci nedeniyle interaktif ortamda oluşturulan anketler, öğretmenlerin mail adreslerine gönderilmiştir. Gönüllülük esasına dayanan çalışmada örneklem rastgele seçilmiştir. Çalışmaya katılan öğretmenlerin betimsel özellikleri Tablo 1.'de verilmiştir.

Tablo 1. Çalışmaya Katılan Öğretmenlerin Betimsel Özellikleri

\begin{tabular}{|c|c|c|}
\hline Cinsiyet & $\mathrm{f}$ & $\%$ \\
\hline Kadın & 115 & 77 \\
\hline Erkek & 35 & 23 \\
\hline Branş & $\mathrm{f}$ & $\%$ \\
\hline Yabancı Dil Öğr. & 18 & 12 \\
\hline Sinıf Öğr. & 35 & 23 \\
\hline Din Kültürü ve Ahlak Bilgisi Öğr. & 33 & 22 \\
\hline Türkçe Öğr. & 28 & 19 \\
\hline Fen Bilgisi Öğr. & 19 & 13 \\
\hline Matematik Öğr. & 17 & 11 \\
\hline Kidem & $\mathrm{f}$ & $\%$ \\
\hline $0-5$ yil & 25 & 17 \\
\hline 6-11 y1l & 48 & 32 \\
\hline $12-15$ yil & 39 & 26 \\
\hline 18 yıl ve üzeri & 38 & 25 \\
\hline Mezun Olunan Fakülte & $\mathrm{f}$ & $\%$ \\
\hline Eğitim Fakültesi & 102 & 68 \\
\hline Fen Edebiyat Fakültesi & 29 & 19 \\
\hline İlahiyat Fakültesi & 18 & 12 \\
\hline Öğrenim Durumu & $\mathrm{f}$ & $\%$ \\
\hline Lisan Mezunu & 124 & 83 \\
\hline Lisansüstü Ĕ̆itim Mezunu & 26 & 24 \\
\hline Görev Yeri & $\mathrm{f}$ & $\%$ \\
\hline İl Merkezi & 121 & 81 \\
\hline İlçe & 29 & 19 \\
\hline
\end{tabular}

Tablo 1 incelendiğinde çalışmaya katılan öğretmenlerin çoğunluğunun kadın olduğu görülmektedir. Çalışmaya en çok sınıf öğretmeninin katıldığı, kıdem değişkenine göre 6-11 yıl çalışma süresinin diğer yıllara göre fazla olduğu, öğretmenlerin çoğunun eğitim fakültesi ve lisans mezunu olduğu, katılımcıların çoğunun il merkezinde görev yaptı̆̆ı görülmektedir.

\section{Veri Toplama Aracı}

Araştırmanın verileri iki farklı ölçek ile toplanmıştır. Öğretmenlerin uzaktan eğitime yönelik tutumlarının belirlenmesi için Ağır (2007) tarafından geliştirilen "Uzaktan Eğitim Tutum Ölçeği” kullanılmıştır. Ölçeğin Cronbach's Alpha iç tutarlılık katsayısı hesaplanmıştır ve değer 0.835 olarak belirlenmiştir. Ölçekte 14 olumlu 7 olumsuz olmak üzere 21 madde yer almaktadır. Ölçeğin puan aralığı 21 ile 105'tir. Bireyin ölçekten aldığ1 puan 
uzaktan eğitime karşı olan tutumunu belirlemektedir. Puan yükseldikçe uzaktan eğitime olumlu bir tutum sergilendiği söylenebilir.

Öğretmenlerin koronavirüs korku düzeylerini belirlemek için Arpacı, Karataş ve Baloğlu (2020) tarafından geliştirilen 20 maddeden oluşan "”' kullanılmıştır. Korona virüse karşı gelişebilen fobiyi ölçümlemek üzere geliştirilen 5'li likert tipi ölçek dört alt boyuttan oluşmaktadır. Ölçek maddeleri; 1 "kesinlikle katılmıyorum” ile 5 “kesinlikle katılıyorum" arasında değerlendirilir. 1., 5., 9., 13., 17. ve 20. maddeler Psikolojik Alt Boyutu; 2. 6. 10. 14. ve 18. maddeler Somatik Alt boyutu; 3. 7. 11. 15. ve 19. maddeler Sosyal Alt boyutu; 4. 8. 12. ve 16. maddeler ise Ekonomik Alt boyutu ölçmektedir. Ölçeğin psikolojik alt boyutundaki maddeler bireyin kendisi ya da yakın çevresine yönelik Covid-19 korkularına yönelik ifadeleri, somatik alt boyutundaki maddeler korkuyla beraber bireyin vücudunda meydana gelen fiziksel tepkilere ait ifadeleri, sosyal alt boyutundaki maddeler bireyin sosyalleşme sürecindeki korkularına yönelik ifadeleri ve ekonomik alt boyutundaki maddeler bireyin yaşadığ COVID-19 korkusuyla beraber aldığı ekonomik önlemelere ait ifadeleri içermektedir. Alt boyut puanları o alt boyuta ait maddelere verilen cevapların puan toplamı ile elde edilirken; toplam C19P-S puanı alt boyut puanlarının toplamı ile elde edilir ve 20 ile 100 puan arasında değişir. Puanların yüksekliği alt boyutlardaki ve genel koronavirüs korkusundaki yüksekliğe işaret eder

\section{Verilerin Toplanması ve Analizi}

Çalışmanın verileri 2020-2021 eğitim öğretim yılı güz döneminde toplanmıştır. Veri toplama aracı uygulanmadan önce katılımcılardan kişisel bilgiler temin edilmiş ve ölçekler hakkında bilgi verişmiştir. Katılımcılar tarafından doldurulan ölçekler kontrol edilerek eksik ve hatalı olanlar çalışmadan çıkarılmıştır. Elde edilen veriler istatistik analiz programı ile analiz edilmiştir. Verilerin normal dağılım gösterip gösterilmediğinin belirlenmesi için Shapiro Wilks testi yapılmıştır (Tablo 2.)

Tablo 2. Koronavirüs 19 Fobisi (CP19-S2) Ölçeği ve Uzaktan Eğitim Tutum Ölçeği Normallik Testi Sonuçları

\begin{tabular}{|c|c|c|}
\hline Ölçek & Değişken & Shapiro Wilks \\
\hline \multirow{2}{*}{ Uzaktan Eğitim Tutum } & Branş & $\begin{array}{c}\text { İngilizce Öğrt.-.058 } \\
\text { Sinıf Öğrrt.-.616 } \\
\text { Din Kült Öğrt.-.486 } \\
\text { Türkçe Öğgrt.-.848 } \\
\text { Fen Bilg. Öğrt.--.311 } \\
\text { Matematik Öğrt.-.220 }\end{array}$ \\
\hline & Kıdem & $\begin{array}{c}\text { 0-5Y1l- .211 } \\
\text { 6-11Y1l- .600 } \\
\text { 12-15Y1l- .359 } \\
18 Y_{11} \text { ve üz.- .191 }\end{array}$ \\
\hline \multirow{3}{*}{ Koronavirüs 19 Fobisi (CP19-S2) } & Branş & $\begin{array}{c}\text { İngilizce Öğrt.-.145 } \\
\text { Sinıf Öğrt.--.248 } \\
\text { Din Kült Öğrt.-.091 } \\
\text { Türkçe Öğgrt.-.059 } \\
\text { Fen Bilg. Öğrt.-.217 } \\
\text { Matematik Öğrt.-.327 }\end{array}$ \\
\hline & Cinsiyet & $\begin{array}{l}\text { Kadın-.074 } \\
\text { Erkek-.228 }\end{array}$ \\
\hline & Kıdem & $\begin{array}{c}0-5 Y_{11}-.224 \\
\text { 6-11Y1l- } .218 \\
\text { 12-15Y1- } .065 \\
18 Y_{11} \text { ve üz.-.051 } \\
\end{array}$ \\
\hline Psikolojik Alt Boyutu & Branş & $\begin{array}{c}\text { İngilizce Öğrt.-.106 } \\
\text { Sınıf Öğrrt.-.399 } \\
\text { Din Kült Öğrt.-.113 } \\
\text { Türkçe Öğgrt.-.326 } \\
\text { Fen Bilg. Öğrt.--893 } \\
\text { Matematik Öğrt.-.063 }\end{array}$ \\
\hline
\end{tabular}




\begin{tabular}{|c|c|c|}
\hline Ölçek & Değişken & Shapiro Wilks \\
\hline & Cinsiyet & $\begin{array}{l}\text { Kadın-.064 } \\
\text { Erkek-.528 }\end{array}$ \\
\hline & Kidem & $\begin{array}{c}\text { 0-5Y11-.231 } \\
\text { 6-11Y1- .050 } \\
\text { 12-15Y1- .068 } \\
18 \text { Yıl ve üz.- .059 }\end{array}$ \\
\hline \multirow{3}{*}{ Somatik Alt boyutu } & Branş & $\begin{array}{l}\text { İngilizce Öğrt.-193 } \\
\text { Sınıf Öğgrt.-040 } \\
\text { Din Kült Öğrt.-013 } \\
\text { Türkçe Öğrt.-000 } \\
\text { Fen Bilg. Öğrt.-126 } \\
\text { Matematik Öğrt.- } 008\end{array}$ \\
\hline & Cinsiyet & $\begin{array}{l}\text { Kadın-.000 } \\
\text { Erkek-.008 }\end{array}$ \\
\hline & Kidem & $\begin{array}{c}\text { 0-5Yıl-.040 } \\
\text { 6-11Yıll-.001 } \\
\text { 12-15Yı1- } .000 \\
18 \text { Yıl ve üz.-.048 }\end{array}$ \\
\hline \multirow{3}{*}{ Sosyal Alt boyutu } & Branş & $\begin{array}{c}\text { İngilizce Öğrt.-.195 } \\
\text { Sinıf Öğrtt.-.057 } \\
\text { Din Kült Öğrt.-.153 } \\
\text { Türkçe Öğrt.-.122 } \\
\text { Fen Bilg. Öğrt.-.055 } \\
\text { Matematik Öğrt.-.927 }\end{array}$ \\
\hline & Cinsiyet & $\begin{array}{l}\text { Kadın-.059 } \\
\text { Erkek-.166 }\end{array}$ \\
\hline & Kıdem & $\begin{array}{c}\text { 0-5Y11- } .055 \\
\text { 6-11Y11- } .056 \\
\text { 12-15Y1- } .054 \\
18 \text { Yıl ve üz.-.124 }\end{array}$ \\
\hline \multirow{3}{*}{ Ekonomik Alt boyutu } & Branş & $\begin{array}{c}\text { İngilizce Öğrt.-.055 } \\
\text { Sinıf Öğrtt.-.069 } \\
\text { Din Kült Öğrt.-.204 } \\
\text { Türkçe Öğrt.-.001 } \\
\text { Fen Bilg. Öğrt.-.242 } \\
\text { Matematik Öğrt.-.298 }\end{array}$ \\
\hline & Cinsiyet & $\begin{array}{l}\text { Kadın-.001 } \\
\text { Erkek-.012 } \\
\end{array}$ \\
\hline & Kıdem & $\begin{array}{c}\text { 0-5Y11- } .015 \\
\text { 6-11Y11- } .023 \\
\text { 12-15Y11- } .002 \\
18 \text { Yıl ve üz.-.312 }\end{array}$ \\
\hline
\end{tabular}

Tablo 2' de değişkenlere yönelik yapılan Shapiro-Wiks testi sonucunda $p>.05$ değeri dağılımın normal ; $p<$ .05 değeri ise dağılımın normal olmadığını göstermektedir. Bu analiz sonucunda, branş ve kıdem değişkenleri açısından öğretmenlerin uzaktan eğitime yönelik tutumlarındaki farklılığı belirlemek için tek yönlü varyans analizi ve cinsiyet değişkeni açısından tutumlardaki farklılı̆̆ı belirlemek için ise bağımsız örneklemeler $\mathrm{t}$ testi yapılmıştır. Branş ve kıdem değişkenleri açısından öğretmenlerin Koronavirüs 19 Fobisi ölçeğinden aldıkları toplam puan ile ölçeğin psikolojik ve sosyal alt boyutlarından aldıkları puanlardaki farklılığı belirlemek için tek yönlü varyans analizi, cinsiyet değişkeni açısından farklılığı belirlemek için ise bağımsız örneklemler $t$ testi yapılmıştır. Branş ve kıdem değişkenleri açısından öğretmenlerin Koronavirüs 19 Fobisi ölçeğinin ekonomik ve somatik alt boyutlarından alınan puanlara yönelik Kruskal Wallis ve cinsiyet değişkenine göre farklılığı belirlemek için ise Mann Whitney U testi yapılmıştır. Ayrıca öğretmenlerin Koronavirüs 19 fobisi ile uzaktan eğitime yönelik tutum arasındaki ilişkiyi belirlemek amacıyla pearson korelasyon analizi yapılmıştır. Veri analiz sürecinde anlamlı farkın etki büyüklüğünün belirlenmesi için Cohens'd hesaplanmıştır. Cohen's d değeri 0.2'den küçük olması zayıf bir etki, 0.5'e yakın olması orta etki, 0.8 ve üzeri ise büyük bir etki olduğunu göstermektedir (Sullivan \& Feinn, 2012). 


\section{Araştırmanın Etik İzinleri}

Etik değerlendirmeyi yapan kurul adı: Selçuk Üniversitesi Eğitim Fakültesi Etik Kurulu

Etik değerlendirme kararının tarihi: 23.02.2021

Etik değerlendirme belgesi sayı numarası: 31570

\section{BULGULAR}

Bu bölümde bulgular, araştırmanın alt problemlerine göre sunulmuştur.

\section{Öğretmenlerin Uzaktan Eğitime Yönelik Tutumlarının Dağılımına Yönelik Bulgular}

Öğretmenlerin uzaktan eğitime yönelik tutumlarının frekans, yüzde ve madde ortalamalarının dağılımı Tablo 3'te verilmiştir.

Tablo 3. Öğretmenlerin Uzaktan Eğitim Tutum Ölçeği Madde Yüzde, Frekans ve Madde Ortalamaları

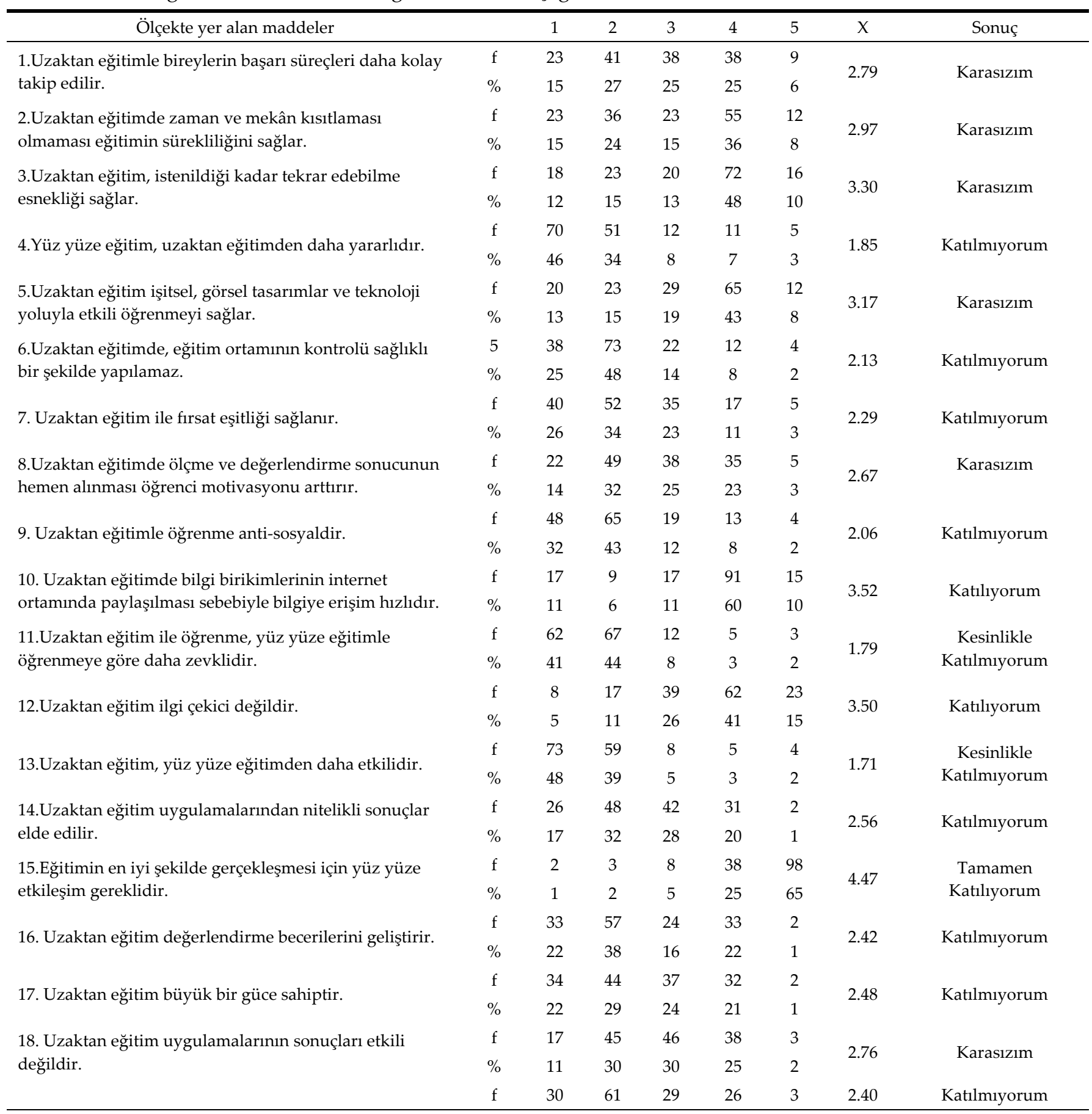




\begin{tabular}{|c|c|c|c|c|c|c|c|c|}
\hline Ölçekte yer alan maddeler & & 1 & 2 & 3 & 4 & 5 & $x$ & Sonuç \\
\hline $\begin{array}{l}\text { 19.Uzaktan eğitim, örgün eğitim uygulamalarında ortaya } \\
\text { çkan birçok problemin çözümünde etkilidir. }\end{array}$ & $\%$ & 20 & 40 & 19 & 17 & 2 & & \\
\hline \multirow{2}{*}{$\begin{array}{l}\text { 20. Uzaktan eğitim, ülkemizde sağ } l_{1} k l_{\curlywedge} \text { bir şekilde } \\
\text { uygulanamaz. }\end{array}$} & $\mathrm{f}$ & 14 & 41 & 31 & 43 & 20 & \multirow{2}{*}{3.09} & \multirow{2}{*}{ Karasızım } \\
\hline & $\%$ & 9 & 27 & 20 & 28 & 13 & & \\
\hline \multirow{2}{*}{$\begin{array}{l}\text { 21. Uzaktan eğitimle herkes kendi düzeyinde eğitim } \\
\text { alabilir. }\end{array}$} & $\mathrm{f}$ & 27 & 42 & 33 & 44 & 3 & \multirow{2}{*}{2.69} & \multirow{2}{*}{ Karasızım } \\
\hline & $\%$ & 18 & 28 & 22 & 29 & 2 & & \\
\hline Toplam & & & & & & & 2.65 & Katılmiyorum \\
\hline
\end{tabular}

Tablo 3. incelendiğinde öğretmenlerin uzaktan eğitime yönelik tutum ölçeğinde yer alan 11 maddede Katılmıyorum ya da Kesinlikle katılmıyorum cevabını verdikleri görülmektedir. Öğretmenlerin yedi maddede kararsız oldukları, "Eğitimin en iyi şekilde gerçekleşmesi için yüz yüze etkileşim gereklidir" maddesine kesinlikle katılıyorum cevabını verdikleri, “Uzaktan eğitim ile öğrenme, yüz yüze eğitimle öğrenmeye göre daha zevklidir” ve "Uzaktan eğitim, yüz yüze eğitimden daha etkilidir" maddesine kesinlikle katılmiyorum cevabı verdikleri görülmektedir.

\section{Branş Değişkenine Göre Öğretmenlerin Uzaktan Eğitime Yönelik Tutumlarına İlişkin Bulgular}

Öğretmenlerin branş değişkenine göre uzaktan eğitime yönelik tutumlarında anlamlı bir farklılık olup olmadığının belirlenmesi amacıyla yapılan Tek Yönlü Varyans Analizi sonuçları Tablo 4'te verilmiştir.

Tablo 4. Branş Değişkenine Göre Öğretmenlerin Uzaktan Eğitime Yönelik Tutumları Tek Yönlü Varyans Analizi Sonuçları

\begin{tabular}{|c|c|c|c|c|c|c|}
\hline \multirow{8}{*}{$\begin{array}{l}\text { Uzaktan } \\
\text { Eğitim Tutum } \\
\text { Ölçeği }\end{array}$} & Branş & $\mathbf{N}$ & $x$ & $\mathrm{~S}$ & $\mathbf{F}$ & $\mathrm{p}$ \\
\hline & 1.İngilizce Öğrt. & 18 & 60,94 & 7,27 & 1,98 & .085 \\
\hline & 2.Sınıf Öğrt. & 35 & 51,37 & 14,01 & & \\
\hline & 3.Din Kül. ve A. Bil. Öğrt. & 33 & 54,12 & 13,61 & & \\
\hline & 4.Türkçe Öğrt. & 28 & 56,89 & 15,38 & & \\
\hline & 5.Fen Bilgisi Öğrt. & 19 & 55,05 & 14,0 & & \\
\hline & 6.Matematik Öğrt. & 17 & 61,18 & 11,61 & & \\
\hline & Toplam & 150 & & & & \\
\hline
\end{tabular}

Tablo 4 incelendiğinde branş değişkenine göre öğretmenlerin uzaktan eğitime yönelik tutum puanlarında anlamlı bir farklılık olmadığı görülmektedir. Bununla birlikte matematik öğretmenlerinin uzaktan eğitime yönelik tutum puan ortalamaları en yüksek iken $(\bar{X}=61,18)$; en düşük tutum puan ortalamaları $(\bar{X}=51,37)$ sinıf öğretmenlerine aittir.

\section{Cinsiyet Değişkenine Göre Öğretmenlerin Uzaktan Eğitime Yönelik Tutumlarına İlişkin Bulgular}

Öğretmenlerin cinsiyet değişkenine göre uzaktan eğitime yönelik tutumlarında anlamlı bir farklılık olup olmadığının belirlenmesi amacıyla yapılan Bağımsız Örneklem T testi sonuçları Tablo 5'te verilmiştir.

Tablo 5. Cinsiyet Değişkenine Göre Öğretmenlerin Uzaktan Eğitime Yönelik Tutumları Bağımsız Örneklem T Testi Sonuçları

\begin{tabular}{lcccccc}
\hline \multicolumn{1}{c}{ Cinsiyet } & $\mathbf{N}$ & $\mathbf{X}$ & $\mathbf{S}$ & Sd & $\mathbf{t}$ & $\mathbf{p}$ \\
\hline Kadın & 115 & 53,52 & 12,85 & 147 & 3,759 & .000 \\
Erkek & 35 & 63,05 & 13,47 & & & \\
\hline
\end{tabular}

Tablo 5 incelendiğinde cinsiyet değişkenine göre öğretmenlerin uzaktan eğitime yönelik tutum puanlarında anlamlı farklılık olduğu görülmektedir. Bu sonuçlara göre erkek öğretmenlerin tutumlarının $(X=63,05)$ kadın öğretmenlere ( $X=53,52)$ göre daha yüksek olduğu görülmektedir. Bu farkın etki büyüklüğü Cohen's d .0.72 olarak belirlenmiştir. Bu durum anlamlı farkın orta düzeyde olduğunu göstermektedir. 
Kıdem Değişkenine Göre Öğretmenlerin Uzaktan Eğitime Yönelik Tutumlarına İlişkin Bulgular

Öğretmenlerin kıdem değişkeni açısından uzaktan eğitime yönelik tutumlarında anlamlı bir farklılık olup olmadığının belirlenmesi amacıyla yapılan Tek Yönlü Varyans Analizi sonuçları Tablo 6'da verilmiştir.

Tablo 6. Kıdem Değişkenine Göre Öğretmenlerin Uzaktan Eğitime Yönelik Tutumları Tek Yönlü Varyans Analizi Sonuçları

\begin{tabular}{|c|c|c|c|c|c|c|c|}
\hline \multirow{5}{*}{$\begin{array}{c}\text { Uzaktan } \\
\text { Eğitim Tutum } \\
\text { Ölçeği }\end{array}$} & Kidem & $\mathbf{N}$ & $x$ & $S$ & $\mathbf{F}$ & $\mathbf{P}$ & $\begin{array}{c}\text { Anlaml } \\
\text { Fark }\end{array}$ \\
\hline & $1.0-5 \mathrm{Y}_{1} \mathrm{l}$ & 24 & 61,70 & 12,17 & 4,314 & .006 & $\begin{array}{l}1-4 \\
2-4\end{array}$ \\
\hline & 2.6-11 Y 11 & 48 & 57,50 & 11,68 & & & \\
\hline & 3.12-15 Y1l & 40 & 55,25 & 13,33 & & & \\
\hline & $4.18 Y_{1} l$ ve üzeri & 38 & 50,07 & 15,06 & & & \\
\hline
\end{tabular}

Tablo 6 incelendiğinde kıdem değişkenine göre öğretmenlerin uzaktan eğitime yönelik tutum puanlarında anlamlı farklılık olduğu belirlenmiştir. Farkın kaynağının belirlenmesi için Tukey testi yapılmıştır. Analiz sonucu Tablo 7'de verilmiştir.

Tablo 7. Kıdem Değişkenine Göre Öğretmenlerin Uzaktan Eğitime Yönelik Tutumlarına İlişkin Tukey Testi Sonuçları

\begin{tabular}{|c|c|c|c|}
\hline Kidem & Kidem & Ortalamalar Farkı & $\mathbf{P}$ \\
\hline \multirow[t]{3}{*}{1} & 2 & 4,20833 &, 576 \\
\hline & 3 & 6,45192 & ,235 \\
\hline & 4 & $11,62939^{*}$ & ,005 \\
\hline \multirow[t]{3}{*}{2} & 1 & $-4,20833$ & ,576 \\
\hline & 3 & 2,24359 & ,858 \\
\hline & 4 & $7,42105^{*}$ & ,049 \\
\hline \multirow[t]{3}{*}{3} & 1 & $-6,45192$ & 235 \\
\hline & 2 & $-2,24359$ & ,858 \\
\hline & 4 & 5,17746 & ,312 \\
\hline \multirow[t]{3}{*}{4} & 1 & $-11,62939^{*}$ & ,005 \\
\hline & 2 & $-7,42105^{*}$ & ,049 \\
\hline & 3 & $-5,17746$ & ,312 \\
\hline
\end{tabular}

Tablo 7 incelendiğinde 6-11 yıl ve 18 yıl ve üzeri arasında kıdeme göre anlamlı fark olduğu, farkın 11 yıl lehine olduğu belirlenmiştir. Ayrıca 18 yıl ve üzeri çalışan öğretmenlere göre 0-5 yıl çalışan öğretmenlerin tutum puanlarının daha yüksek olduğu tespit edilmiştir.

\section{Öğretmenlerin Koronavirüs Korku Düzeylerine İlişkin Bulgular}

Öğretmenlerin koronavirüs korku düzeyleri frekans, yüzde ve madde ortalamaları dağılımı Tablo 8'de verilmiştir.

Tablo 8. Öğretmenlerin Koronavirüs 19 Fobisi Ölçeği madde yüzde, frekans ve madde ortalamaları

\begin{tabular}{|c|c|c|c|c|c|c|c|c|}
\hline Ölçekte yer alan maddeler & & 1 & 2 & 3 & 4 & 5 & $x$ & Sonuç \\
\hline \multirow{2}{*}{$\begin{array}{l}\text { 1. Koronavirüs kapma korkusu beni çok } \\
\text { kaygılandırıyor. }\end{array}$} & $\mathrm{f}$ & 5 & 29 & 56 & 31 & 28 & \multirow{2}{*}{3,32} & \multirow{2}{*}{ Karasızım } \\
\hline & $\%$ & 3,3 & 19,3 & 37,3 & 20,7 & 18,7 & & \\
\hline \multirow{2}{*}{$\begin{array}{l}\text { 2.Koronavirüs sebebiyle karnıma ağrılar } \\
\text { giriyor. }\end{array}$} & $\mathrm{f}$ & 50 & 73 & 11 & 10 & 5 & \multirow{2}{*}{1,97} & \multirow{2}{*}{ Katılmiyorum } \\
\hline & $\%$ & 33,3 & 48,7 & 7,3 & 6,7 & 3,3 & & \\
\hline \multirow{2}{*}{$\begin{array}{l}\text { 3.Öksüren insanları görünce koronavirüs } \\
\text { şüphesiyle aşırı kaygılanıyorum. }\end{array}$} & $\mathrm{f}$ & 11 & 42 & 47 & 27 & 22 & \multirow{2}{*}{3,04} & \multirow{2}{*}{ Karasızım } \\
\hline & $\%$ & 7,3 & 28,0 & 31,3 & 18,0 & 14,7 & & \\
\hline \multirow{2}{*}{$\begin{array}{l}\text { 4. Koronavirüs nedeniyle yiyecek } \\
\text { maddelerinin tükenmesinden kaygılanıyorum. }\end{array}$} & $\mathrm{f}$ & 36 & 61 & 30 & 13 & 9 & \multirow{2}{*}{2,31} & \multirow{2}{*}{ Katılmıyorum } \\
\hline & $\%$ & 24,0 & 40,7 & 20,0 & 8,7 & 6,0 & & \\
\hline
\end{tabular}

|Manisa Celal Bayar University Journal of The Faculty of Education, 2021, Vol.9, No. 2| 


\begin{tabular}{|c|c|c|c|c|c|c|c|c|}
\hline Ölçekte yer alan maddeler & & 1 & 2 & 3 & 4 & 5 & $x$ & Sonuç \\
\hline \multirow{2}{*}{$\begin{array}{l}\text { 5. Ailemden birinin koronavirüse yakalanma } \\
\text { olasılığından aşırı derecede korkuyorum. }\end{array}$} & $\mathrm{f}$ & 5 & 16 & 48 & 22 & 58 & \multirow{2}{*}{3,75} & \multirow{2}{*}{ Katıliyorum } \\
\hline & $\%$ & 3,3 & 10,7 & 32,0 & 14,7 & 38,7 & & \\
\hline \multirow{2}{*}{ 6. Koronavirüs sebebiyle göğsüm ağrıyor. } & 5 & 53 & 73 & 15 & 6 & 2 & \multirow{2}{*}{1,86} & \multirow{2}{*}{ Katılmiyorum } \\
\hline & $\%$ & 35,3 & 48,7 & 10,0 & 4,0 & 1,3 & & \\
\hline \multirow{2}{*}{$\begin{array}{l}\text { 7.Hapşıran insanlardan koronavirüs } \\
\text { şüphesiyle kaçarcasına uzaklaşıyorum. }\end{array}$} & $\mathrm{f}$ & 18 & 45 & 46 & 16 & 24 & \multirow{2}{*}{2,88} & \multirow{2}{*}{ Karasızım } \\
\hline & $\%$ & 12,0 & 30,0 & 30,7 & 10,7 & 16,0 & & \\
\hline \multirow{2}{*}{$\begin{array}{l}\text { 8.Koronavirüs nedeniyle temizlik } \\
\text { maddelerinin tükenmesinden endişeliyim. }\end{array}$} & $\mathrm{f}$ & 35 & 88 & 15 & 8 & 3 & \multirow[t]{2}{*}{2,03} & \multirow[t]{2}{*}{ Katılmiyorum } \\
\hline & $\%$ & 23,3 & 58,7 & 10,0 & 5,3 & 2,0 & & \\
\hline \multirow{2}{*}{$\begin{array}{l}\text { 9. Koronavirüsten ölüm haberleri beni müthiş } \\
\text { derecede kaygılandırıyor. }\end{array}$} & $\mathrm{f}$ & 9 & 39 & 64 & 12 & 25 & \multirow{2}{*}{3,03} & \multirow{2}{*}{ Kararsızım } \\
\hline & $\%$ & 6,0 & 26,0 & 42,7 & 8,0 & 16,7 & & \\
\hline \multirow{2}{*}{$\begin{array}{l}\text { 10. Koronavirüs sebebiyle aniden elim ayağım } \\
\text { titremeye başlıyor. }\end{array}$} & $\mathrm{f}$ & 63 & 76 & 5 & 4 & 1 & \multirow{2}{*}{1,68} & \multirow{2}{*}{$\begin{array}{l}\text { Kesinlikle } \\
\text { Katılmıyorum }\end{array}$} \\
\hline & $\%$ & 42,0 & 50,7 & 3,3 & 2,7 & ,7 & & \\
\hline \multirow{2}{*}{$\begin{array}{l}\text { 11. Koronavirüs sebebiyle, ellerimi } \\
\text { temizlemek için aşırı zaman harcadığımın } \\
\text { farkındayım. }\end{array}$} & $\mathrm{f}$ & 24 & 65 & 27 & 21 & 12 & \multirow[b]{2}{*}{2,54} & \multirow[b]{2}{*}{ Katılmıyorum } \\
\hline & $\%$ & 16,0 & 43,3 & 18,0 & 14,0 & 8,0 & & \\
\hline \multirow{2}{*}{ 12. Koronavirüs korkusuyla gıda stokluyorum. } & $\mathrm{f}$ & 42 & 67 & 34 & 5 & 1 & \multirow{2}{*}{2,03} & \multirow{2}{*}{ Katılmiyorum } \\
\hline & $\%$ & 28,0 & 44,7 & 22,7 & 3,3 &, 7 & & \\
\hline \multirow{2}{*}{$\begin{array}{l}\text { 13. Koronavirüsle ilgili belirsizlikler beni ciddi } \\
\text { manada kaygılandırıyor. }\end{array}$} & $\mathrm{f}$ & 7 & 42 & 55 & 20 & 25 & \multirow{2}{*}{3,09} & \multirow{2}{*}{ Karasızım } \\
\hline & $\%$ & 4,7 & 28,0 & 36,7 & 13,3 & 16,7 & & \\
\hline \multirow{2}{*}{$\begin{array}{l}\text { 14. Koronavirüs nedeniyle uyku problemi } \\
\text { yaşıyorum. }\end{array}$} & $\mathrm{f}$ & 64 & 57 & 18 & 8 & 2 & 1,83 & Katılmiyorum \\
\hline & $\%$ & 42,7 & 38,0 & 12,0 & 5,3 & 1,3 & 1,83 & Katımiyorum \\
\hline 15. Koronavirüse yakalanmak korkusu sosyal & $\mathrm{f}$ & 16 & 40 & 44 & 17 & 32 & 3,06 & Karasızım \\
\hline ilişkilerimi ciddi anlamda sekteye uğruyor. & $\%$ & 10,7 & 26,7 & 29,3 & 11,3 & 21,3 & 0,00 & Narasizm \\
\hline 16. Koronavirüsten sonra, evdeki ihtiyaç & $\mathrm{f}$ & 34 & 68 & 26 & 15 & 6 & & \\
\hline $\begin{array}{l}\text { malzemelerini kontrol etmezsem içim rahat } \\
\text { etmiyor. }\end{array}$ & $\%$ & 22,7 & 45,3 & 17,3 & 10,0 & 4,0 & 2,26 & Katılmiyorum \\
\hline 17. Koronavirsün yayılma hızı beni aşırı & $\mathrm{f}$ & 15 & 46 & 58 & 13 & 17 & 280 & Kararsizim \\
\hline derecede panikletiyor. & $\%$ & 10,0 & 30,7 & 38,7 & 8,7 & 11,3 & 2,80 & Kararsizim \\
\hline 18. Koronavirüs beni o kadar gerginleştiriyor & $\mathrm{f}$ & 49 & 71 & 16 & 11 & 2 & & \\
\hline $\begin{array}{l}\text { ki, normalde yapabileceğim şeyleri bile } \\
\text { yapamıyorum. }\end{array}$ & $\%$ & 32,7 & 47,3 & 10,7 & 7,3 & 1,3 & 1,96 & Katılmiyorum \\
\hline 19. Başkalarından koronavirüsle kapma & $\mathrm{f}$ & 25 & 47 & 53 & 15 & 9 & 257 & Katılmivorum \\
\hline korkusundan kendimi alamiyorum. & $\%$ & 16,7 & 31,3 & 35,3 & 10,0 & 6,0 & 2, & 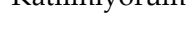 \\
\hline 20. Koronavirüse karşı insanların duyarsız & $\mathrm{f}$ & 20 & 44 & 57 & 16 & 12 & 2,70 & \\
\hline $\begin{array}{l}\text { davranmaları sebebiyle çevremdekılerle } \\
\text { tartışmak istiyorum (ya da tartışıyorum). }\end{array}$ & $\%$ & 13,3 & 29,3 & 38,0 & 10,7 & 8,0 & & Kararsızım \\
\hline Toplam & & & & & & & 2,53 & Katılmiyorum \\
\hline
\end{tabular}

Tablo 8 incelendiğinde öğretmenlerin Koronavirüs 19 Fobisi ölçeğinde yer alan maddelere çoğunlukla katılmıyorum cevabını verdikleri görülmektedir. Öğretmenler sadece "Koronavirüs sebebiyle aniden elim ayağım titremeye başlıyor" maddesine kesinlikle katılmıyorum cevabını, "Ailemden birinin koronavirüse yakalanma olasılığından aşırı derecede korkuyorum" maddesine katılıyorum cevabını verdikleri, ölçekte yer alan diğer tüm maddelerde ise kararsız oldukları görülmektedir.

\section{Branş Değişkenine Göre Öğretmenlerin Koronavirüs Korku Düzeylerine İlişkin Bulgular}

Branş değişkenine göre öğretmenlerin Koronavirüs 19 Fobisi ölçeğinden aldıkları toplam puan ile ölçeğin psikolojik ve sosyal alt boyutlarından aldıkları puanlardaki farklılığı belirlemek için tek yönlü varyans analizi yapılmıştır. Analiz sonucu Tablo 9.'da verilmiştir. 
Tablo 9. Branş Değişkenine Göre Öğretmenlerin Koronavirüs 19 Fobisi Ölçeği Toplam Puanları, Psikolojik ve Sosyal Alt Boyutları Tek Yönlü Varyans Analizi Sonuçları

\begin{tabular}{|c|c|c|c|c|c|c|}
\hline \multirow{7}{*}{$\begin{array}{l}\text { Psikolojik Alt } \\
\text { Boyut }\end{array}$} & Branş & $\mathbf{N}$ & $x$ & Ss & $\mathbf{F}$ & $\mathbf{P}$ \\
\hline & 1.İngilizce Öğrt. & 18 & 20,0000 & 4,89898 & \multirow{6}{*}{.997} & \multirow{6}{*}{.422} \\
\hline & 2.Sınıf Öğrt. & 35 & 18,3429 & 5,26890 & & \\
\hline & 3.Din Kült. Ahl. Bilg. Öğrt. & 33 & 19,3636 & 6,31377 & & \\
\hline & 4.Türkçe Öğrt. & 28 & 18,2143 & 5,77579 & & \\
\hline & 5.Fen Bilgisi Öğrt. & 19 & 19,5789 & 5,11334 & & \\
\hline & 6.Matematik Öğrt. & 17 & 16,5625 & 2,89756 & & \\
\hline \multirow{6}{*}{$\begin{array}{c}\text { Sosyal Alt } \\
\text { Boyut }\end{array}$} & 1.İngilizce Öğrt. & 18 & 13,8889 & 3,39357 & \multirow{6}{*}{.129} & \multirow{6}{*}{.986} \\
\hline & 2.Sınıf Öğrt. & 35 & 14,5714 & 5,48949 & & \\
\hline & 3.Din Kült ve Ahl Bilg. Öğrt. & 33 & 14,0000 & 5,54527 & & \\
\hline & 4.Türkçe Öğrt. & 28 & 14,1429 & 5,23319 & & \\
\hline & 5.Fen Bilgisi Öğrt. & 19 & 14,1579 & 4,31101 & & \\
\hline & 6.Matematik Öğrt. & 17 & 13,4375 & 4,24215 & & \\
\hline \multirow{6}{*}{ Toplam } & 1.İngilizce Öğrt. & 18 & 52,8333 & 13,40435 & \multirow{6}{*}{.580} & \multirow{6}{*}{.715} \\
\hline & 2.Sınıf Öğrt. & 35 & 51,6286 & 15,39115 & & \\
\hline & 3.Din Kült Ahl Bilg. Öğrt. & 33 & 51,4545 & 16,93017 & & \\
\hline & 4.Türkçe Öğrt. & 28 & 49,7500 & 16,80305 & & \\
\hline & 5.Fen Bilgisi Öğrt. & 19 & 52,3684 & 14,41531 & & \\
\hline & 6.Matematik Öğrt. & 17 & 45,3125 & 9,88412 & & \\
\hline
\end{tabular}

Tablo 9 incelendiğinde branş değişkenine göre öğretmenlerin Koronavirüs 19 Fobisi ölçeği toplam puanı ve Psikolojik ve Sosyal Alt Boyutlarından aldıkları puanlarda anlamlı bir fark olmadığı belirlenmiştir.

Branş değişkenine göre öğretmenlerin Koronavirüs 19 Fobisi ölçeğinin ekonomik ve somatik alt boyutlarından alınan puanlara yönelik Kruskal Wallis ve testi yapılmıştır. Analiz sonuçları Tablo 10'da verilmiştir.

Tablo 10. Branş Değişkenine Göre Öğretmenlerin Koronavirüs Ölçeği Ekonomik ve Somatik Alt Boyutları Kruskal Wallis Testi Analizi Sonuçları

\begin{tabular}{|c|c|c|c|c|c|c|}
\hline & Branş & $\mathbf{N}$ & Sira & S.S. & $\mathrm{X} 2$ & $\mathbf{P}$ \\
\hline \multirow{5}{*}{$\begin{array}{c}\text { Ekonomik Alt } \\
\text { Boyut }\end{array}$} & 1.İngilizce Ö̆̆rt. & 18 & 74,17 & \multirow{6}{*}{3.079} & \multirow{6}{*}{8.651} & \multirow{6}{*}{.347} \\
\hline & 2.Sınıf Ö̆̆grt. & 35 & 84,39 & & & \\
\hline & 3.Din Kült. Ahl. Bilg. Öğrt. & 33 & 74,67 & & & \\
\hline & 4.Türkçe Ö̈̆rt. & 28 & 66,86 & & & \\
\hline & 5.Fen Bilgisi Öğrt. & 19 & 84,03 & & & \\
\hline \multirow{7}{*}{ Somatik Boyut } & 6.Matematik Öğrt. & 17 & 59,63 & & & \\
\hline & 1.İngilizce Öğrt. & 18 & 87,33 & \multirow{6}{*}{3.559} & \multirow{6}{*}{9.328} & \multirow{6}{*}{.293} \\
\hline & 2.Sınıf Öğrt. & 35 & 80,90 & & & \\
\hline & 3.Din Kült. Ahl. Bilg. Öğrt. & 33 & 76,56 & & & \\
\hline & 4.Türkçe Öğrt. & 28 & 68,64 & & & \\
\hline & 5.Fen Bilgisi Öğrt. & 19 & 75,53 & & & \\
\hline & 6.Matematik Öğrt. & 17 & 55,50 & & & \\
\hline
\end{tabular}

Tablo 10 incelendiğinde branş değişkenine göre öğretmenlerin Koronavirüs 19 Fobisi ölçeği Ekonomik ve Somatik Alt Boyutlarından aldıkları puanlarda anlamlı bir fark olmadığı belirlenmiştir. 
Cinsiyet Değişkenine Göre Öğretmenlerin Koronavirüs Korku Düzeylerine İlişkin Bulgular

Cinsiyet değişkenine göre öğretmenlerin ölçeğin psikolojik ve sosyal alt boyutlarından aldıkları puanlardaki farklılığı belirlemek bağımsız örneklemler t testi yapılmıştır. Analiz sonuçları Tablo 11'de verilmiştir.

Tablo 11. Cinsiyet Değişkenine Göre Öğretmenlerin Koronavirüs 19 Fobisi Ölçeği Psikolojik ve Sosyal Alt Boyutları Bağımsız Örneklem $\mathrm{t}$ testi Sonuçları

\begin{tabular}{|c|c|c|c|c|c|c|c|}
\hline & Cinsiyet & $\mathbf{N}$ & $x$ & $S$ & Sd & $t$ & $\mathrm{p}$ \\
\hline \multirow{2}{*}{$\begin{array}{l}\text { Psikolojik Alt } \\
\text { Boyut }\end{array}$} & Kadın & 115 & 19,3130 & 5,37108 & \multirow[t]{2}{*}{147} & \multirow[t]{2}{*}{2.562} & \multirow[t]{2}{*}{.483} \\
\hline & Erkek & 35 & 16,6765 & 4,91578 & & & \\
\hline \multirow{2}{*}{ Sosyal Alt Boyut } & Kadın & 115 & 14,4435 & 5,10279 & \multirow[t]{2}{*}{147} & \multirow[t]{2}{*}{1.545} & \multirow[t]{2}{*}{.112} \\
\hline & Erkek & 35 & 12,9706 & 4,04134 & & & \\
\hline \multirow{2}{*}{ Toplam } & Kadin & 115 & 52,2696 & 15,47852 & \multirow[t]{2}{*}{147} & \multirow[t]{2}{*}{2.214} & \multirow[t]{2}{*}{.028} \\
\hline & Erkek & 35 & 45,8235 & 12,76708 & & & \\
\hline
\end{tabular}

Tablo 11 incelendiğinde cinsiyet değişkenine göre öğretmenlerin Koronavirüs 19 Fobisi ölçeği psikolojik ve sosyal alt boyutlarında anlamlı bir fark olmadığı, ancak ölçeğin bütünü için kadın öğretmenler lehine anlamlı bir farkın olduğu belirlenmiştir. Bu farkın etki büyüklüğü Cohen's d .046 olarak belirlenmiştir. Bu durum anlamlı farkın zayıf olduğunu göstermektedir.

Cinsiyet değişkenine göre öğretmenlerin ölçeğin ekonomik ve somatik alt boyutlarından aldıkları puanlardaki farklılığı belirlemek için Mann Whitney U testi yapılmıştır. Analiz sonuçları Tablo 12' de verilmiştir.

Tablo 12. Cinsiyet Değişkenine Göre Öğretmenlerin Koronavirüs 19 Fobisi Ölçeği Ekonomik ve Somatik Alt Boyutları Mann Sonuçları Whitney U Testi Sonuçları

\begin{tabular}{lcccccc}
\hline & Cinsiyet & N & Sira Ortalamasi & Sira Toplami & U & P \\
\hline $\begin{array}{l}\text { Ekonomik Alt } \\
\text { Boyut }\end{array}$ & Kadın & 115 & 78,81 & 9063,00 & 1517,000 & .046 \\
\cline { 2 - 7 } & Erkek & 35 & 62,12 & 2112,00 & & 1576,500 \\
\hline \multirow{2}{*}{$\begin{array}{l}\text { Somatik Alt } \\
\text { Boyut }\end{array}$} & Kadın & 115 & 78,29 & & & .084 \\
\cline { 2 - 7 }
\end{tabular}

Tablo 12 incelendiğinde cinsiyet değişkenine göre öğretmenlerin Koronavirüs 19 Fobisi Ölçeği Ekonomik alt boyutunda kadın öğretmenler lehine anlamlı bir fark olduğu belirlenmiştir. Bu farkın etki büyüklügü 0.027 olarak belirlenmiş̧ir. Bu durum anlamlı farkın zayıf olduğunu göstermektedir.

\section{Kıdem Değişkenine Göre Öğretmenlerin Koronavirüs Korku Düzeylerine İlişkin Bulgular}

Kıdem değişkenine göre öğretmenlerin Koronavirüs 19 Fobisi ölçeğinden aldıkları toplam puan ile ölçeğin psikolojik ve sosyal alt boyutlarından aldıkları puanlardaki farklılığı belirlemek için tek yönlü varyans analizi yapılmıştır. Analiz sonucu Tablo 13'te verilmiştir.

Tablo 13. Kıdem Değişkenine Göre Öğretmenlerin Koronavirüs 19 Fobisi Ölçeği Toplam Puan ve Psikolojik ve Sosyal Alt Boyutları Tek Yönlü Varyans Analizi Sonuçları

\begin{tabular}{|c|c|c|c|c|c|c|}
\hline \multirow{6}{*}{$\begin{array}{c}\text { Psikolojik Alt } \\
\text { Boyut }\end{array}$} & Kidem & $\mathbf{N}$ & $x$ & S & $\mathbf{F}$ & $\mathrm{p}$ \\
\hline & $1.0-5 Y_{1}$ & 24 & 18,6250 & 4,87061 & \multirow{4}{*}{1.313} & \multirow{4}{*}{.273} \\
\hline & 2.6-11 Y Yl & 48 & 19,6875 & 4,92564 & & \\
\hline & $3.12-15 Y_{11}$ & 40 & 17,4103 & 5,91927 & & \\
\hline & $4.18 Y_{1} l$ ve üzeri & 38 & 18,8684 & 5,54671 & & \\
\hline & $1.0-5 Y_{11}$ & 24 & 14,0833 & 4,23152 & \multirow{4}{*}{1.206} & \multirow{4}{*}{.210} \\
\hline \multirow{3}{*}{ Sosyal Alt Boyut } & 2.6-11 Y 11 & 48 & 14,8333 & 4,99929 & & \\
\hline & 3.12-15 Y1l & 40 & 12,8974 & 4,72839 & & \\
\hline & $4.18 \mathrm{Y}_{1} \mathrm{l}_{\mathrm{ve}}$ üzeri & 38 & 14,4474 & 5,30526 & & \\
\hline Toplam & $1.0-5 Y_{1}$ & 24 & 49,5000 & 13,6063 & .807 & .492 \\
\hline
\end{tabular}




\begin{tabular}{|c|c|c|c|c|c|c|}
\hline \multirow{8}{*}{$\begin{array}{c}\text { Psikolojik Alt } \\
\text { Boyut }\end{array}$} & Kidem & $\mathbf{N}$ & $x$ & S & F & $\mathrm{p}$ \\
\hline & $1.0-5 Y_{1}$ & 24 & 18,6250 & 4,87061 & \multirow{7}{*}{1.313} & \multirow{7}{*}{.273} \\
\hline & 2.6-11 Y 11 & 48 & 19,6875 & 4,92564 & & \\
\hline & 3.12-15 Yil & 40 & 17,4103 & 5,91927 & & \\
\hline & $4.18 Y_{11}$ ve üzeri & 38 & 18,8684 & 5,54671 & & \\
\hline & 2.6-11 Yil & 48 & 52,8333 & 13,6589 & & \\
\hline & $3.12-15 Y_{11}$ & 40 & 517995 & & & \\
\hline & $4.18 Y_{11}$ ve üzeri & 38 & 50,7987 & & & \\
\hline
\end{tabular}

Tablo 13 incelendiğinde öğretmenlerin kıdem değişkenine göre öğretmenlerin Koronavirüs 19 Fobisi ölçeği toplam puanı ve Psikolojik ve Sosyal alt boyutlarından aldıkları puanlarda anlamlı bir farklılık olmadığı görülmektedir.

Kıdem değişkenine göre öğretmenlerin Koronavirüs 19 Fobisi ölçeğinin ekonomik ve somatik alt boyutlarından alınan puanlara yönelik Kruskal Wallis ve testi yapılmıştır. Analiz sonuçları Tablo 14'te verilmiştir.

Tablo 14. Kıdem Değişkenine Göre Öğretmenlerin Koronavirüs 19 Fobisi Ölçeği Ekonomik ve Somatik Alt Boyutları Kruskal Wallis Analizi Sonuçları

\begin{tabular}{|c|c|c|c|c|c|c|}
\hline \multirow{5}{*}{$\begin{array}{c}\text { Ekonomik Alt } \\
\text { Boyut }\end{array}$} & Kidem & $\mathbf{N}$ & Sira & S.S. & $X 2$ & $\mathrm{p}$ \\
\hline & $1.0-5 \mathrm{Y}_{1} \mathrm{l}$ & 24 & 67,15 & 3,079 & 3.730 & .292 \\
\hline & 2.6-11 Y 11 & 48 & 79,14 & & & \\
\hline & 3.12-15 Y 11 & 40 & 67,28 & & & \\
\hline & $4.18 Y_{11}$ ve üzeri & 38 & 82,66 & & & \\
\hline \multirow{4}{*}{ Somatik Boyut } & $1.0-5 Y_{11}$ & 24 & 67,02 & 3,559 & 1.374 & .712 \\
\hline & 2.6-11 Y 11 & 48 & 78,78 & & & \\
\hline & 3.12-15 Yil & 40 & 73,17 & & & \\
\hline & $4.18 Y_{11}$ ve üzeri & 38 & 77,14 & & & \\
\hline
\end{tabular}

Tablo 14 incelendiğinde kıdem değişkenine göre öğretmenlerin Koronavirüs 19 Fobisi ölçeğinin Ekonomik ve Somatik alt boyutlarından aldıkları puanlarda anlamlı bir farklılık olmadığı görülmektedir.

\section{Öğretmenlerin Uzaktan Eğitime Yönelik Tutumları ile Koronavirüs Korku Düzeyleri Arasında İlişkiye Yönelik Bulgular}

Öğretmenlerin uzaktan eğitime yönelik tutumları ile koronavirüs korkuları arasında anlamlı bir fark olup olmadığının belirlenmesi için Pearson korelasyon katsayısı hesaplanmıştır. Analiz sonucu Tablo 15'te verilmiştir.

Tablo 15. Öğretmenlerin Uzaktan Eğitime Yönelik Tutumları ile Koronavirüs Korkuları Arasındaki İlişki

\begin{tabular}{lccc}
\hline & Uzaktan Eğitim & Koronavirüs Fobi \\
\cline { 2 - 4 } & Pearson & 1 & .059 \\
Uzaktan Eğitim & Correlation & & .473 \\
& Sig. (2-tailed) & & 150 \\
& $\mathrm{~N}$ & 150 & .059 \\
Koronavirüs Fobi & Pearson & .473 & 1 \\
& Correlation & 150 & 150 \\
\hline
\end{tabular}

Tablo 15 incelendiğinde öğretmenlerin uzaktan eğitime yönelik tutumları ile koronavirüs korkuları arasında anlamlı bir ilişki olmadığı görülmektedir. 
SONUÇ ve TARTIŞMA

Bu çalışmada, Covid-19 salgınıyla geçilen uzaktan eğitim uygulamalarıyla birlikte; öğretmenlerin çeşitli değişkenler bakımından hem uzaktan eğitime yönelik tutumları hem de Covid-19 korku düzeyleri incelenmiştir. Bununla birlikte öğretmenlerin uzaktan eğitime yönelik tutumları ile Covid-19 korku düzeyleri arasında bir ilişki olup olmadığı da analiz edilmiştir. Araştırmadan elde edilen sonuçlar ilgili literatürle tartışılırken; bu sonuçların pandemi ve sonrasında yapılacak eğitim-öğretim sürecindeki düzenlemelere katkı sunacağı düşünülmektedir.

Araştırmaya katılan öğretmenlerin uzaktan eğitime yönelik tutum ölçeğine verdikleri cevaplar incelendiğinde; öğretmenler uzaktan eğitimin yüz yüze eğitim kadar etkili, zevkli ve sonuçlarının nitelikli olduğunu düşünmemektedir. Bununla birlikte, ölçeğin geneli ele alındığında; öğretmenlerin uzaktan eğitime yönelik tutumlarının "Katılmıyorum" düzeyinde olduğu görülmektedir. Yani, öğretmenlerin uzaktan eğitime yönelik olumsuz tutuma sahip oldukları söylenebilir. Elde edilen bu sonuç, Moçoşoğlu ve Kaya (2020), Kurnaz, Kaynar, Şentürk-Barışık ve Doğrukök (2020) tarafından yürütülen çalışmaların bulgularıyla örtüşürken; Kuşkonmaz (2011), Ülkü (2018) ve Kocayiğit ve Uşun (2020) tarafından yapılan araştırma sonuçlarıyla çelişmektedir. Burada dikkat çeken husus ise; benzer sonuçlara sahip çalışmaların da Covid-19 sürecinde yürütülmüş olmasıdır.

Araştırmada öğretmenlerin uzaktan eğitime yönelik tutumlarında branşa göre farklılaşma görülmemiştir. Elde edilen bu sonuç, Ağır (2007)'ın ve Kocayiğit ve Uşun (2020)'nin yürüttükleri çalışma sonuçlarıyla örtüşmektedir. Cinsiyet değişkenine göre, öğretmenlerin uzaktan eğitime yönelik tutumları incelendiğindeyse; erkek öğretmenlerin tutum puanlarının anlamlı düzeyde yüksek olduğu görülmüştür. Bu sonuç, yapılan benzer çalışmaların sonuçlarıyla çelişse de literatürde cinsiyete göre uzaktan eğitim tutum puanları arasında farklı sonuçlar elde edildiği görülmektedir. Bazı çalışmalar da cinsiyete göre öğretmenlerin uzaktan eğitime yönelik tutum puanlarında anlamlı fark yokken (Ağır, 2007; Horzum, 2003; Kuşkonmaz, 2011; Tırnovalı, 2012; Ülkü, 2018) bazı çalışmalarda ise bu fark kadın öğretmenler lehinedir (Alea, Fabrea, Roldan ve Farooqi, 2020; Kurnaz, Kaynar, Şentürk-Barışık ve Doğrukök, 2020). Yapılan bu çalışma için, ortaya çıan farklı sonucun sebeplerinden biri kadın ve erkek öğretmen sayısı arasındaki önemli fark olabilir.

Araştırmaya katılan öğretmenlerin uzaktan eğitime yönelik tutumları ile mesleki kıdem değişkeni arasında anlamlı bir farklılaşmanın olduğu görülmektedir. Yapılan analiz sonuçları, mesleki kıdemi "0-5 yıl" olan öğretmenlerin, mesleki kıdemi "18 yıl ve üzeri" olan öğretmenlere göre; yine mesleki kıdemi "6-11 yıl” olan öğretmenlerin, mesleki kıdemi "18 yıl ve üzeri" olan öğretmenlere göre tutum puanlarının anlamlı düzeyde yüksek olduğunu göstermektedir. Bu bulguyla benzer sonuçlara ulaşan çalışmalara rastlamak mümkündür (Ağır, 2007; Alea, Fabrea, Roldan ve Farooqi, 2020; Moçoşoğlu ve Kaya, 2020). Araştırmacılara göre bu durumun nedenlerinden biri; mesleki deneyimi az olan öğretmenlerin daha genç olması nedeniyle bilgisayar ve diğer teknolojik araç gereçleri daha fazla kullanıyor olmasıdır. Bir diğer nedeni ise; daha yakın geçmişte mezun olan öğretmenlerin lisans eğitimleri sürecinde teknolojik araç-gereçler hakkında daha fazla bilgi sahibi olmalarından kaynaklanıyor olabilir. Bununla birlikte öğretmenlerle yürütülen bazı çalışmalarda ise; mesleki kıdem değişkeninin uzaktan eğitime yönelik tutum için anlamlı bir farklılık oluşturmadığı görülmüştür (Kocayiğit ve Uşun, 2020; Kurnaz, Kaynar, Şentürk-Barışık ve Doğrukök, 2020; Ülkü, 2018).

Öğretmenlerin "Koronavirüs-19 Fobisi Ölçeği”nden aldıkları puan ortalamaları incelendiğinde; öğretmenlerin Covid-19'a yönelik korkularının düşük düzeyde olduğu görülmektedir. Öğretmenlerin anket sorularına verdikleri yanıtlardan, Covid-19 korkusuna yönelik vücutlarında meydana gelebilecek el titremesi, karın ağrısı ya da yüksek düzeyde korku gibi herhangi bir fizyolojik/psikolojik bir problem yaşamadıkları görülmektedir. Öğretmenler, ölçekte yer alan "Koronavirüs sebebiyle aniden elim ayağım titremeye başlıyor" maddesine kesinlikle katılmıyorum cevabını verirken; "Koronavirüs sebebiyle karnıma ağrılar giriyor.", "Koronavirüs beni o kadar gerginleştiriyor ki, normalde yapabileceğim şeyleri bile yapamıyorum.", "Başkalarından koronavirüs kapma korkusundan kendimi alamıyorum." maddelerine katılmadıklarını belirtmiş̧lerdir. Bununla birlikte, öğretmenler aile yakınlarının koronavirüse yakalanmasından oldukça korkmaktadır. Bu araştırmadan elde edilen sonucun 
aksine; Çiçek, Tanhan, Arslan ve Buluş (2020) tarafından öğretmenlerle gerçekleştirilen bir çalışmada Covid-19 salgınının, öğretmenlerin depresyon ve kaygı durumlarını yükselttiği belirlenmiştir. Katılımcılarını farklı meslek gruplarının oluşturduğu Göksu ve Kumcağız (2020)'ın çalışmasında da öğretmenlerin kaygı düzeylerinin yüksek olduğu dikkat çekmektedir. Filipinli öğretmenlerle yürütülen bir başka çalışmada ise yine, öğretmenlerin Covid19'a yönelik yüksek kaygı düzeyine sahip oldukları belirlenmiştir (Talidong ve Toquero, 2020). Bu farklılığın nedenleri, örneklemin yaşadığı coğrafi bölgedeki ya da çalışma ortamlarındaki Covid-19 vakalarının yoğunluğuyla ilişkili olabilir. Bir diğer önemli neden de araştırmanın yürütüldüğü süreçte bireylerin koronavirüs pandemi sürecine artık alışmış olması da olabilir.

Öğretmenlerin branş ve mesleki kıdem değişkenleri göz önüne alındığında; öğretmenlerin “Koronavirüs-19 Fobisi Ölçeği"nin genelinden ve ölçeğin alt boyutların aldıkları puan ortalamaları arasında anlamlı bir istatistiksel farklılık görülmemiştir. Bununla birlikte, kadın öğretmenlerin koronavirüs korku düzeyleri, ölçekten elde edilen toplam puan ve "ekonomik" alt boyutunda anlamlı düzeyde yüksektir. Çiçek, Tanhan, Arslan ve Buluş (2020) tarafından yürütülen çalışmada da kadın öğretmenlerin erkeklere göre yüksek düzeyde depresyon ve kaygı yaşadıkları tespit edilmiştir. Farklı örneklemler üzerinde yapılan araştırmalarda da kadınların Covid-19 salgınına yönelik kayg1, korku düzeylerinin yüksek olduğu sonucuna ulaşılmıştır (Göksu ve Kumcağız, 2020; Wang vd., 2020; Zhang vd., 2020).

Araştırmada, öğretmenlerin Covid-19'a yönelik korku düzeyleri ile uzaktan eğitime yönelik tutumları arasında anlamlı bir ilişkinin olmadığı sonucuna ulaşılmıştır. Her ne kadar araştırmacılar tarafından Covid-19'a yönelik korku düzeyindeki artışın, öğretmenlerin uzaktan eğitime yönelik tutumlarını olumlu yönde etkileyeceği düşünülse de elde edilen sonuçlar bu hipotezi çürütmüştür.

\section{ÖNERILER}

Araştırmadan elde edilen sonuçlar ışı̆̆ında, şu önerilerde bulunulabilir:

- Çalışmanın önemli sınırlılığı örneklem sayısıdır. Örneklem genişletilerek benzer çalışmalar yürütülebilir.

- Öğretmenlerin uzaktan eğitime yönelik tutumlarını ve Covid-19'a karşı korku düzeylerini etkileyebilecek farklı faktörler (ikamet edilen yer, görev yeri gibi) çalışmaya dahil edilebilir.

- Literatür tarandığında, ülkemizde, pandeminin öğretmenler üzerindeki psikolojik etkilerini araştıran çalışmaların sayısının yok denecek kadar az olduğu görülmüştür. Bu bağlamda bu konuya yönelik çalışmaların artırılması önerilmektedir.

- Bu çalışmada nicel araştırma yöntemleri kullanılsa da nitel araştırma yöntemlerinin kullanılarak öğretmen görüşlerinin daha derinlemesine ele alındığı farklı çalışmalar yürütülebilir. 
KAYNAKÇA

Ağır, F. (2007). Özel okullarda ve devlet okullarında çalışan ilköğretim öğretmenlerinin uzaktan eğitime karşı tutumlarının belirlenmesi (Yayımlanmamış Yüksek Lisans Tezi). Balıkesir Üniversitesi, Fen Bilimleri Enstitüsü, Balıkesir.

Alea, L. A., Fabrea, M. F., Roldan, R. D. A., \& Farooqi, A. Z. (2020). Teachers' Covid-19 awareness, distance learning education experiences and perceptions towards institutional readiness and challenges. International Journal of Learning, Teaching and Educational Research, 19(6), https://doi.org/10.26803/ijlter.19.6.8

Arpacı, I., Karataş, K., \& Baloğlu, M. (2020). The development and initial tests for the psychometric properties of the COVID-19 Phobia Scale (C19P-S). Personality and Individual Differences, 164, 110-108.

Ateş, A. \& Altun, E. (2008). Bilgisayar öğretmeni adaylarının uzaktan eğitime yönelik tutumlarının çeşitli değişkenler açısından incelenmesi, Gazi Ĕ̆itim Fakültesi Dergisi, 28(3), 125-145.

Aydın, İ. E. (2012). Relationship between affective learning, instructor attractiveness and instructor evaluation in videoconference-based distance education courses. The Turkish Online Journal of Educational Technology, 11(4), 247-252.

Balaman, F. (2018). Web tabanlı uzaktan eğitim ile geleneksel eğitimin internet programcıllğı 2 dersi kapsamında karşılaştırılması. Itobiad: Journal of the Human \& Social Science Researches, 7(2), 1173-1200.

Basilaia, G., \& Kvavadze, D. (2020). Transition to online education in schools during a SARS-CoV-2 coronavirus (COVID-19) pandemic in Georgia. Pedagogical Research, 5(4), 1-9.

Bates, A. T. (2005). Technology, e-learning and distance education. Oxford: Routledge.

Bayraktar, G., Tozoğlu, E. \& Acar, K. (2014). Öğretmen adayların kaygı düzeyleri üzerinde spor ve farklı değişkenlerin etkisi. Erzincan Üniversitesi Eğitim Fakültesi Dergisi, 16 (1), 305- 315.

Birişçi, S. (2013). Video konferans tabanlı uzaktan eğitime ilişkin öğrenci tutumları ve görüşleri. Journal of Instructional Technologies \& Teacher Education, 2(1), 24-40.

Birol, C., \& Teker, N. (2002). Uzaktan eğitim süreçlerinde kullanılan basılı materyallere yönelik toplam kalite analizi (aü açıöğretim fakültesi örneği) [Total quality analysis about the printed material used at the distance education], presented paper at AÖF'ün 20. Yılı Nedeniyle Uluslararası Katılımlı Açık ve Uzaktan Eğitim Sempozyumu. Anadolu University, May 23- 25, 2002, Eskisehir, Turkey.

Bodur, F. (2002). Anadolu üniversitesi uzaktan eğitim sisteminde basılı ders malzemelerinin basım ve dağıtım organizasyonu [Printing and Distribution Organization of the Printed Course Materials at Anadolu's Distance Education System] presented paper at AÖF'ün 20. Yılı Nedeniyle Uluslararası Katılımlı Açık ve Uzaktan Eğitim Sempozyumu. Anadolu Universitesi, May 23-25, 2002, Eskisehir, Turkey. (Published in symposium proceedings).

Burgess, S., \& Sievertsen, H. H. (2020). Schools, skills, and learning: The impact of COVID-19 on education. VoxEu. org, 1(2).

Cao, W., Fang, Z., Hou, G., Han, M., Xu, X., Dong, J., \& Zheng, J. (2020). The psychological impact of the COVID-19 epidemic on college students in China. Psychiatry research, 112934.

Cavanaugh, C. S. (2001). The effectiveness of interactive distance education technologies in K-12 learning: A metaanalysis. International Journal of Educational Telecommunications 7(1), 73-88.

Check J., \& Schutt, R. K. (2012) Survey research. In: J. Check, R. K. Schutt., editors. Research methods in education. Thousand Oaks, CA: Sage Publicatio. pp. 159-185.

Cırık, M. (2016). Uzaktan eğitimin üstün zekâlı öğrencilerin eğitimindeki yeri. Açı̈öğretim Uygulamaları ve Araştırmaları Dergisi, 2(3), 170-187.

Çelen, F. K., Çelik, A. \& Seferoğlu, S. S. (2013). Analysis of teachers' approaches to distance education. Procedia-Social and Behavioral Sciences, 83, 388-392. 
Çiçek, İ., Tanhan, A., Arslan, G. \& Buluş, M. (2020). (İnceleme altında/ manuscript under review). Psychological Inflexibility Predictis Depression and Anxiety during COVID-19: Acceptance and Commitment Therapy Perspective. doi: 10.13140/RG.2.2.32134.19526.

Gonzalez, T., De La Rubia, M. A., Hincz, K. P., Comas-Lopez, M., Subirats, L., Fort, S., \& Sacha, G. M. (2020). Influence of COVID-19 confinement on students' performance in higher education. PloS one, 15(10), e0239490.

Göksu, Ö. \& Kumcağız, H. (2020). Covid-19 salgınında bireylerde algılanan stres düzeyi ve kaygı düzeyleri. Turkish Studies, 15(4), 463-479. https://dx.doi.org/10.7827/TurkishStudies.44397

Hamutoğlu, N. B., Gültekin, G. S., \& Savaşçı, M. (2019). Öğretmen adaylarının uzaktan eğitime yönelik görüşleri: Açıöğretim uygulamaları. Yükseköğretim Dergisi, 9(1), 19-28.

Horzum, M. B. (2003). Öğretim elemanlarının internet destekli eğitime yönelik düşünceleri (Sakarya Üniversitesi Örneği) (Yayınlanmamış Yüksek Lisans Tezi). Sakarya Üniversitesi Sosyal Bilimler Enstitüsü, Sakarya.

Huang, L. ve Rong Liu, H. (2020). Emotional responses and coping strategies of nurses and nursing college students during COVID-19 outbreak: A comparative study. PLoS One, 15(8), 1-12. https://doi.org/10.1371/journal.pone.0237303

Ilmiyah, S., \& Setiawan, A. R. (2020). Students' worksheet for distance learning based on scientific literacy in the topic coronavirus disease 2019 (COVID-19) https://doi.org/10.31237/osf.io/fpg4j

Kocayiğit, A. \& Uşun, S. (2020). Millı̂ Eğitim Bakanlığına bağlı okullarda görev yapan öğretmenlerin uzaktan eğitime yönelik tutumları (Burdur ili Örneği). Avrasya Uluslararası Araştırmalar Dergisi, 8(23), 285-299. https://doi.org/10.33692/avrasyad.662503

Kurnaz, A., Kaynar, H., Şentürk-Barışık, C. \& Doğrukök, B. (2020). Öğretmenlerin uzaktan eğitime yönelik görüşleri. Milli Ĕ̆itim, 49(Özel sayı), 293-322.

Kuşkonmaz, H. (2011). İlköğretim okullarındaki öğretmenlerin mobil öğrenmeye yönelik algı düzeylerinin belirlenmesi (Yayımlanmamış Yüksek Lisans Tezi). Bahçeşehir Üniversitesi, İstanbul.

Liu, X., Liu, J., \& Zhong, X. (2020). Psychological state of college students during covid-19 epidemic. Available at SSRN 3552814. http://dx.doi.org/10.2139/ssrn.3552814

Moçoşoğlu, B. \& Kaya, A. (2020). Koronavirüs hastalığı (COVID-19) sebebiyle uygulanan uzaktan eğitime yönelik öğretmen tutumlarının incelenmesi. Kahramanmaraş Sütçü İmam Üniversitesi Ĕ̆itim Dergisi, 2(1), 15-43.

Ojo, D.O., \& Olakuluhin, F.K. (2006). Attitudes and perceptions of students to open and distance learning in Nigeria, International Review of Research in Open and Distance Learning, 7(1), 1-10.

Öztürk, Y. A., Şahin, Ç., Demir, M. K. \& Arcagök, S. (2019). Temel eğitim bölümünde öğrenimlerini sürdüren öğretmen adaylarının öğretmenlik mesleğine yönelik kaygı düzeylerinin incelenmesi. Eskişehir Osmangazi Üniversitesi Sosyal Bilimler Dergisi, 20, 107-122.

Pragholapati, A. (2020). COVID-19 impact on students.10. 10. 2021 tarihinde https://edarxiv.org/895ed adresinden alınmıştır.

Sahu, P. (2020). Closure of universities due to Coronavirus Disease 2019 (COVID-19): Impact on education and mental health of students and academic staff. Cureus, 12(4). https://doi.org/10.7759/cureus.7541

Sanderson, E., \& Greenberger, R. (2010). Evaluating online programs through a gifted lens. Gifted Child Today, 34(3), $42-53$.

Setiawan, A. R. (2020). Scientific literacy worksheets for distance learning in the topic of coronavirus 2019 (COVID19) 26.05.2020 tarihinde https://edarxiv.org/swjmk/ adresinden alınmıştır.

Singleton R. A., \& Straits B. C. (2019). Approaches to social research. New York: Oxford University Press.

Suanpang, P., Petocz, P., \& Kalceff, W. (2004). Student attitudes to learning business statistics: Comparison of online and traditional methods. Educational Technology \& Society, 7 (3), 9-20. 
Sullivan, G. M., \& Feinn, R. (2012). Using effect size-or why the p value is not enough. Journal of Graduate Medical Education, 4(3), 279-282. https://doi.org/10.4300/JGME-D-12-00156.1

Rundle, A. G., Park, Y., Herbstman, J. B., Kinsey, E. W., \& Wang, Y. C. (2020). COVID-19-Related school closings and risk of weight gain among children. Obesity, 28(6), 1008-1009.

Talidong, K.J.B., \& Toquero, C.M.D. (2020) Philippine teachers' practices to deal with anxiety amid COVID-19. Journal of Loss and Trauma, 25(6-7), 573-579. https://doi.org/10.1080/15325024.2020.1759225

Tezcan, M. (2001). Türk yükseköğretiminde örgün eğitim ile uzaktan eğitim sisteminde önlisans eğitiminin maliyetetkinlik analizi [Cost-Activity Analysis of Distance Education and Tradiational Education Higher Education in Turkey]. Ulusal Meslek Yüksekokulları Sempozyum Bildirileri. Marmara Üniversitesi Teknik Bilimler Meslek Yüksekokulu, pp:1-18, 18-19 Ekim 2001, İstanbul, Turkey.

Thomson, D. (2010). Conversations with teachers on the benefits and challenges of online learning for gifted students. Gifted Child Today, 34(3), 31-40.

Tirnovalı, A. (2012). Uzaktan eğitimde internet tabanlı eğitim programlarının temel boyutlarına yönelik öğrenci ve öğretim elemanlarının görüşleri ve öneriler (Yayımlanmamış Doktora Tezi). Mersin Üniversitesi Eğitim Bilimleri Enstitüsü, Mersin.

Tuncer, M. \& Tanaş, R. (2011). Akademisyenlerin uzaktan eğitim programlarına yönelik görüşlerinin değerlendirilmesi (Fırat ve Tunceli Üniversiteleri örneği). İlköğretim Online, 10(2), 776-784.

Ural, O. (2007). Attidues of graduate students toward distance education, educational technologies and independent learning, Turkish Online Journal of Distance Education, 8(4), 34-43.

Ülkü, S. (2018). İlkokullarda görev yapan öğretmenlerin uzaktan eğitime yönelik tutumları (Yayımlanmamış Yüksek Lisans Tezi). Abant İzzet Baysal Üniversitesi, Bolu.

Van Lancker, W., \& Parolin, Z. (2020). COVID-19, school closures, and child poverty: a social crisis in the making. The Lancet Public Health, 5(5), 243-244. https://doi.org/10.1016/S2468-2667(20)30084-0

Wang, C., Cheng, Z., Yue, X. G., \& McAleer, M. (2020). Risk management of COVID-19 by universities in China. Journal of Risk Financial Management, 13(36), 3-6.

Xiao, C. (2020). A novel approach of consultation on 2019 novel coronavirus (COVID-19)-Related psychological and mental problems: structured letter therapy. Psychiatry Investigation, 17 (2), 175-176.

Viner, R. M., Russell, S. J., Croker, H., Packer, J., Ward, J., Stansfield, C., ... \& Booy, R. (2020). School closure and management practices during coronavirus outbreaks including COVID-19: a rapid systematic review. The Lancet Child \& Adolescent Health, 4(5), 397-404.

Yıldırım, T., Çırak, Y. \& Konan, N. (2011). Öğretmen adaylarında sosyal kaygı. Inonu University Journal of the Faculty of Education (INUJFE), 12(1), 85-100.

Yılmaz, E. O. \& Aktuğ, S. (2011). Uzaktan eğitimde çevrimiçi ders veren öğretim elemanlarının, uzaktan eğitimde etkileşim ve iletişim üzerine görüşleri. Akademik Bilişim, Malatya, 2-4 Şubat.

Zhang, W., Wang, K., Yin, L., Zhao, W., Xue, Q., Peng, M., Min, B., Tian, Q, Leng, H., Du, J., Chang, H., Li, W., Shangguan, F., Yan, T., Dong, H., Han, Y., Wang, Y., Cosci, F., \& Wang, H. (2020). Mental health and psychosocial problems of medical health workers during the covid-19 epidemic in china. Psychotherapy and Psychosomatics, 89, 242-250 http://dx.doi.org/10.1159/000507639. 


\section{Extended Abstract}

\section{Introduction}

The aim of this study is to examine teachers' attitudes towards distance education and Covid-19 fears in terms of different variables. In addition, another aim of the study is to determine the relationship between teachers' attitudes towards distance education and Covid-19 fears. Due to the changing conditions in epidemic, many teachers and students around the world are turning to distance education every day. Educational institutions review programs and infrastructure features for distance education, but for many institutions, this situation poses a problem with its technical dimension. Other problems, not limited to technical aspects, have also started to appear. Problems experienced in network connections due to busyness, problems experienced by students who cannot participate in the process because there is no computer facility and internet connection in the home environment, difficulties experienced in conducting applied courses (such as laboratory, music, art) with distance education are the other problems encountered. In addition, the quality of distance education is one of the issues that should be examined at this point (Sahu, 2020). Although it is considered useful due to the lack of time and place limitations, there are some elements that teachers should pay attention to in distance education activities. For example, in the evaluation phase of the distance education process, teachers should plan carefully and carry out the process accordingly. However, the provision, supervision and use of additional materials, the participation of students in distance education, and the control of course follow-up pose a problem for teachers from time to time (Gonzalez et. al. 2020). This situation may cause teachers to have a negative attitude towards distance education. If the teacher has a negative attitude towards distance education, it will be difficult for the teacher to benefit from the opportunities offered by distance education and the learning process will be negatively affected (Birişçi, 2013).

\section{Method}

In this study, the survey model was used. The sample of the study consists of 150 teachers working in different branches and as data collection tool, the Attitude Scale towards Distance Education developed by Ağ1r (2007) and the Covid-19 Phobia Scale developed by Arpacı, Karataş, and Baloğlu (2020) were used as data collection tools.

\section{Findings}

In this study, it was found that teachers do not consider distance education is as effective, enjoyable and qualified as face-to-face education. According to the gender variable, when teachers' attitudes towards distance education are examined; male teachers' attitude scores were found to be significantly higher. However, there was no difference in the attitudes of teachers towards distance education according to the branch and professional seniority. When the average scores of the teachers from the "Coronavirus-19 Phobia Scale" are examined, it is seen that their fear of Covid-19 is at a low level. In addition, considering the branch and professional seniority variables of teachers there was no statistically significant difference between the overall scores of the teachers in the "Coronavirus-19 Phobia Scale" and the mean scores of the sub-dimensions of the scale. Finally, it was concluded that there was no significant relationship between teachers' fear levels towards Covid-19 and their attitudes towards distance education.

\section{Result and Discussion}

Results obtained from the research shows that teachers' attitudes towards distance education are negative and Covid-19 fear levels are low. Moreover, in the study, it was determined that there was no significant relationship between teachers' attitudes towards distance education and Covid-19 fear levels. It can be said that teachers have negative attitudes towards distance education. While this result is in line with the findings of the studies carried out by Moçoşoğlu and Kaya (2020), Kurnaz, Kaynar, Şentürk-Barışık, and Doğrukök (2020); it contradicts the results of the research conducted by Kuşkonmaz (2011), Ülkü (2018) and Kocayiğit and Uşun (2020). The point that draws attention here is the fact that studies with similar results were also carried out during the Covid-19 process.

According to the gender variable, when teachers' attitudes towards distance education are examined; male teachers' attitude scores were found to be significantly higher. While in some studies there is no significant difference 
in the scores of teachers' attitude towards distance education according to gender (Ağ1r, 2007; Horzum, 2003; Kuşkonmaz, 2011; Tırnovalı, 2012; Ülkü, 2018), in some studies, this difference is in favor of female teachers (Alea, Fabrea, Roldan, \& Farooqi, 2020; Kurnaz, Kaynar, Şentürk-Barışık, \& Doğrukök, 2020). For this study, one of the reasons for the different result may be the significant difference between the number of male and female teachers.

According to researchers, one of the reasons for this situation is that teachers with less professional experience use computers and other technological tools more because they are younger. Another reason may be due to the fact that teachers who graduated more recently have more information about technological tools and equipment during their undergraduate education. However, in some studies conducted with teachers it has been observed that the variable of professional seniority does not make a significant difference for the attitude towards distance education (Kocayiğit \& Uşun, 2020; Kurnaz, Kaynar, Şentürk-Barışık, \& Doğrukök, 2020; Ülkü, 2018).

When the average scores of the teachers from the "Coronavirus-19 Phobia Scale" are examined it is seen that teachers' fear of Covid-19 is at a low level. In the study, it was concluded that there was no significant relationship between teachers' fear levels towards Covid-19 and their attitudes towards distance education. Although it is thought by researchers that the increase in the level of fear towards Covid-19 will positively affect teachers' attitudes towards distance education the results obtained disproved this hypothesis.

\section{Araştırmanın Etik İzinleri}

Yapılan bu çalışmada "Yükseköğretim Kurumları Bilimsel Araştırma ve Yayın Etiği Yönergesi" kapsamında uyulması belirtilen tüm kurallara uyulmuştur. Yönergenin ikinci bölümü olan “Bilimsel Araştırma ve Yayın Etiğine Aykırı Eylemler" başlığı altında belirtilen eylemlerden hiçbiri gerçekleştirilmemiştir.

Etik değerlendirmeyi yapan kurul adı: Selçuk Üniversitesi Eğitim Fakültesi Etik Kurulu

Etik değerlendirme kararının tarihi: 23.02.2021

Etik değerlendirme belgesi sayı numarası: 31570 